\section{Micropropagation of Agave americana}

\author{
Ying Chen
}

Department of Plant Sciences, University of Tennessee, 349 Plant Biotech Building, Knoxville, TN 37996-4561; and the College of Forest Resource and Environment, Nanjing Forestry University, Nanjing, Jiangsu, 210037, China

Xinlu Chen

Department of Plant Sciences, University of Tennessee, 349 Plant Biotech Building, Knoxville, TN 37996-4561

Fei Hu, Hua Yang and Li Yue

College of Forest Resource and Environment, Nanjing Forestry University, Nanjing, Jiangsu, 210037, China

\section{Robert N. Trigiano}

Department of Entomology and Plant Pathology, University of Tennessee, Knoxville, TN 37996-4560

\section{Zong-Ming (Max) Cheng ${ }^{1}$ \\ Department of Plant Sciences, University of Tennessee, 349 Plant Biotech Building, Knoxville, TN 37996-4561}

\section{Additional index words. auxin, cytokinin, cytology, organogenesis, regeneration}

\begin{abstract}
Agave species are economically important plants in tropical and subtropical desert ecosystems as ornamentals as well as potential bioenergy crops. However, their relatively long life cycles and the current lack of biotechnology tools hinder their breeding. In this study, an efficient system for micropropagation was developed for Agave americana L. by using basal stems as explants and grown on a modified Murashige and Skoog medium (MSI) or a 1/2 MSI medium supplemented with various concentrations of 6-benzylaminopurine (BA) for shoot proliferation. The highest number of shoots (18.5 shoots/explant) from basal stems was obtained on MSI supplemented with 13.32 $\mu$ M BA. An efficient shoot regeneration system was also developed from leaf tissues. Combinations of auxin with cytokinin, basal media, and leaf regions were optimized for shoot induction. Adventitious shoot formation from leaf segments was induced and proliferated with combination ranging of 0.54 to $2.68 \mu M[\alpha$-naphthaleneacetic acid (NAA)] with 8.88 to $13.32 \mu \mathrm{M}(\mathrm{BA})$, and the maximum frequency $(\approx 69 \%)$ was obtained with 2.68 $\mu M$ NAA plus 13.32 $\mu$ M BA. MSI medium and the basal segment of leaf affected shoot induction. The highest rooting frequency and mean number of shoots occurred in $1 / 2$ MSI containing with $4.92 \mu \mathrm{M}$ indole-3-butyric acid (IBA) alone $(90 \%, 3.4)$ or $1.48 \mu \mathrm{M}$ IBA plus $1.61 \mu M$ NAA $(92 \%, 5.2)$. Survival of in vitro plantlets after transfer and acclimatization to ex vitro conditions was $87 \%$. This is the first complete protocol for micropropagation of $A$. americana.
\end{abstract}

Agave species (Agave L.) are important species in tropical and subtropical ecosystems and are also cultivated as ornamentals. They have been recently recognized as highly promising bioenergy plants because they yield high cellulosic biomass while using water three to six times more efficiently than any of the current candidate crops for biomass

Received for publication 24 Sept. 2013. Accepted for publication 2 Jan. 2014.

Funding for this work is provided by the Program for Priority Academic Program Development of Jiangsu Province, the Natural Science Foundation of China (31270711), the Program for Innovative Research Team in Universities of Educational Department, the Tennessee AgResearch Innovation Grant, and University of Tennessee Institute of Agriculture for providing materials and laboratories to complete this study.

${ }^{1}$ To whom reprint requests should be addressed; e-mail zcheng@utk.edu.
(Martínez-Palacios et al., 2003; Portillo et al., 2007; Santacruz-Ruvalcaba and Portillo, 2009). Shoots have been induced using bulbil, rhizome, stem, and leaf explants in $A$. arizonica Perrine ex Engelm (Powers and Backhaus, 1989), A. fourcroydes Lemaire (Robert et al., 1987), and A. sisalana Perrine ex Engelm (Das, 1992; Hazra et al., 2002); using leaf segments and meristematic tissue in A. tequilana F.A.C Weber (ValenzuelaSánchez et al., 2006); and using axillary shoots in A. parrasana A. Berger (SantacruzRuvalcaba et al., 1999). Somatic embryogenesis (SE) has also been reported in A. fourcroydes using apical meristems (González et al., 2003), in A. victoriae-reginae T. Moore using stem segments (Martínez-Palacios et al., 2003), in A. salmiana Otto ex Salm-Dyck using stems (Flores-Benítez et al., 2007), in A. tequilana using leaves (Portillo et al., 2007, 2012; Rodriguez-Sahagun et al., 2011; Santacruz-Ruvalcaba and Portillo, 2009), and in $A$. sisalana using young leaves (Nikam et al., 2003). However, shoot propagation, SE, and plant regeneration of $A$. americana have not been reported.

The aim of this work was to establish a high-frequency shoot micropropagation and plant regeneration protocol for A. americana, a giant agave native to Central America, which can grow in arid, semiarid, tropical, and subtropical regions such as the southern United States, North Africa, Mexico, India, and southern China (Jin et al., 2003, 2004; Lachenmeier et al., 2006; Nasri and Ben Salemn, 2012). Recently, some researchers have evaluated Agave as a bioenergy feedstock because of its stem carbohydrates and leaf lignocelluloses (Debnath et al., 2010; Garcia-Moyae et al., 2011; Jaouadiet al., 2011; Somerville et al., 2010). The efficient protocols of micropropagation and regeneration developed in this research will benefit future clonal propagation, breeding, and biotechnologybased genetic improvement.

\section{Materials and Methods}

Plant materials and in vitro germination. Seeds of $A$. americana (purchased from CactusStore.com; <http://www.cactusstore. com $>$ ) were soaked in distilled water for $24 \mathrm{~h}$. They were surface-sterilized in $70 \%$ $(\mathrm{v} / \mathrm{v})$ ethanol for $2 \mathrm{~min}$, then immersed in $20 \%(\mathrm{v} / \mathrm{v})$ commercial bleach $(1.5 \% \mathrm{NaOCl})$ with several drops of Tween 20 for $20 \mathrm{~min}$, and followed by rinsing three times with sterile distilled water. After blotting them on sterile filter paper to remove excess water, they were planted in $150 \times 20$-mm culture tubes containing $20 \mathrm{~mL}$ Murashige and Skoog (1962) (MS) basal medium supplemented with $30 \mathrm{~g} \cdot \mathrm{L}^{-1}$ sucrose, $7 \mathrm{~g} \cdot \mathrm{L}^{-1}$ agar, $\mathrm{pH} 5.8$ for germination. Leaves and basal stems of 6-week-old seedlings were used as explants and incubated with a $16-\mathrm{h}$ photoperiod at $25 \pm 1{ }^{\circ} \mathrm{C}$ with $55 \mu \mathrm{mol} \cdot \mathrm{m}^{-2} \cdot \mathrm{s}^{-1}$ fluorescent illumination.

Culture medium and culture conditions. Four media used in this study were: MS medium, modified MS medium (MSI) 
containing MS basal salts (Sigma-Aldrich; M5524), $250 \mathrm{mg} \cdot \mathrm{L}^{-1}$ 2-(N-morpholino) ethane sulfonic acid, $200 \mathrm{mg} \cdot \mathrm{L}^{-1}$ L-glutamine, 100 $\mathrm{mg} \cdot \mathrm{L}^{-1}$ myo-inositol, and $100 \mathrm{mg} \cdot \mathrm{L}^{-1}$ each of nicotinic acid, pyridoxine $\mathrm{HCl}$, calcium pantothenate, thiamine $\mathrm{HCl}$, and L-cysteine, Driver and Kuniyuki Walnut (DKW) medium (Driver and Kuniyuki,1984), and Woody plant medium (WPM; Lloyd and McCown, 1981). All media were supplemented with $30 \mathrm{~g} \cdot \mathrm{L}^{-1}$ sucrose and adjusted to $\mathrm{pH} 5.8$ with $1 \mathrm{M} \mathrm{KOH}$ before the addition of $7 \mathrm{~g} \cdot \mathrm{L}^{-1}$ agar and then autoclaved for $20 \mathrm{~min}$ at $121^{\circ} \mathrm{C}$. All plant growth regulators (PGRs) (see specific experiments) were filter-sterilized into media after autoclaving unless stated otherwise. Cultures were incubated at $25 \pm 1{ }^{\circ} \mathrm{C}$ with a 16-h photoperiod using $55 \mu \mathrm{mol} \cdot \mathrm{m}^{-2} \cdot \mathrm{s}^{-1}$ fluorescent illumination.

Shoot multiplication from explants of basal stems. Basal stems, $\approx 0.3 \mathrm{~cm}$ long, were isolated from 6-week-old defoliated seedlings and transferred onto MSI or $1 / 2 \mathrm{MSI}$ (1/2 MS basal salts) media supplemented with $2.2,4.4,8.8$, or $13.2 \mu \mathrm{M}$ of BA for inducing axillary shoots. Explants were placed in $200 \mathrm{~mL}(9.5 \mathrm{~cm}$ high $\times 4.5 \mathrm{~cm}$ diameter) baby food jars containing $50 \mathrm{~mL}$ of medium. Microcuttings were transferred to fresh media every $30 \mathrm{~d}$. The longest leaves were measured after $30 \mathrm{~d}$ and the numbers of shoots were recorded after 30 and $50 \mathrm{~d}$, respectively. The gain of fresh weight (FW) after $30 \mathrm{~d}$ was determined as follows:

$$
\begin{aligned}
& \text { FW gain }(\mathrm{g})=\text { explant weight after } 30 \mathrm{~d} \\
& \text { of culture }(\mathrm{g})-\text { initial weight }(\mathrm{g})
\end{aligned}
$$

Shoot regeneration from leaf explants. To determine the effect of PGRs on shoot induction, leaves from 6-week-old plantlets were cut into $\approx 0.5-\mathrm{cm}$ long sections and incubated on MSI medium containing 0 , $2.22,4.44,8.88,13.32 \mu \mathrm{M}$ BA in all combinations with $0,0.54,2.68,5.36 \mu \mathrm{M}$ NAA. Leaf segments were placed in petri dishes $(1.5 \times 8.5 \mathrm{~cm})$ containing $20 \mathrm{~mL}$ medium. Explants were subcultured to the same fresh medium every 30 d. Explant morphology, callus induction frequency, and percentage of explants forming shoots and shoot numbers were recorded after 30, 60, 90, and $120 \mathrm{~d}$.

To test how different leaf regions affected shoot formation, leaves ( $\approx 3 \mathrm{~cm}$ long) were cut transversely into five segments: one basal, two middle, and two apical. These segments were placed onto MSI in sequential order and media were supplemented with $2.68 \mu \mathrm{M}$ NAA and $13.32 \mu \mathrm{M}$ BA or $5.34 \mu \mathrm{M}$ NAA and $4.44 \mu \mathrm{M}$ BA. Each treatment had three replicates per replication with 16 leaf segments.

Histology light microscopy. For histology, samples were fixed in formalin, acetic acid, alcohol solution (FAA) containing 70\% ethanol, $5 \%$ glacial acetic acid, and 5\% formaldehyde at room temperature for $24 \mathrm{~h}$. After fixation, samples were dehydrated with a graded series of isopropanol $(50 \%, 75 \%$, $85 \%, 95 \%$, and $100 \%$ ) and then embedded in Paraplast Plus blocks $\left(58\right.$ to $60{ }^{\circ} \mathrm{C}$ ). Sections $(10-\mu \mathrm{m}$ thick) were obtained using a micro- tome and stained with safranin $\mathrm{O}$, crystal violet, and fast green (Jensen, 1962). The sections were viewed using a microscope (Olympus BX51; <http://www.olympusamerica. com $>$ ) equipped with a digital camera (Olympus Q-Color 5; < http://www.olympusamerica.com>) for photomicrography.

Rooting induction from microshoots. The effects of IBA and NAA and their concentrations on root induction from plantlets were examined. Shoots separated from clusters on basal stems or on leaf segments were cultured in $1 / 2$ MSI medium supplemented with 0 , $0.49,1.48,2.46$, or $4.92 \mu \mathrm{M}$ IBA alone; 0 , $0.54,1.61,2.68$, or $5.36 \mu \mathrm{M}$ NAA alone; or a combination of IBA with NAA $(1.48+$ $2.68,2.46+2.68$, or $4.92+5.36 \mu \mathrm{M}, \mathrm{IBA}+$ NAA) (Table 5). Rooting percentage, root number, and maximum root length were recorded after 10 and $20 \mathrm{~d}$ in culture.

Acclimatization. Plantlets $\approx 3$ to $4 \mathrm{~cm}$ high with healthy roots were gently washed in tap water to remove agar residue and transplanted to wide pots $(10 \times 8.5 \mathrm{~cm})$ containing PRO-Mix soil (Premier Horticulture, Quebec, Canada). Pots were covered for $2 \mathrm{~d}$ with transparent polystyrene jars with holes to maintain high humidity. Plants were watered with inorganic salt solution [nitrogen:15\%, phosphorus $\left(\mathrm{P}_{2} \mathrm{O}_{5}\right): 16 \%$, potassium $\left(\mathrm{K}_{2} \mathrm{O}\right): 17 \%$, magnesium: $0.055 \%$, boron: $0.02 \%$, copper: $0.0075 \%$, iron: $0.075 \%$, manganese: $0.042 \%$, molybdenum: $0.0075 \%$, zinc: $0.012 \%$; Peters ${ }^{\circledR}$ System of Plant Nutrition, Scotts-Sierra Horticultural Products Company, Marysville, $\mathrm{OH}$ ) once daily for the first $2 \mathrm{~d}$ and every other day thereafter and grown in a growth chamber (85\% humidity, $25 \pm 1{ }^{\circ} \mathrm{C}, 16$-h photoperiod with $55 \mu \mathrm{mol} \cdot \mathrm{m}^{-2} \cdot \mathrm{s}^{-1}$ fluorescent light). Plant survival was recorded after 6 weeks.

Data analysis. Experiments were repeated three times. Each experiment was performed using eight replicates (bottles) with three explants each for shoot proliferation from basal stems, three replicates (dishes) with 16 leaf segments each for shooting from leaves, and 10 replicates (bottles) with two explants each for rooting. Data were subjected to analysis of variance or regression analysis, and the means \pm SES was calculated using Duncan's multiple-range test (Duncan, 1955) with SPSS 17.0 Version $(<\mathrm{https} / / /$ www14.software.ibm.com $>$ ). $P$ values $\leq 0.05$ or 0.01 were considered to represent significant differences among treatments.

\section{Results}

Shoot proliferation from basal stem regions. Media (MSI or 1/2 MSI), BA, and media $\times$ BA interaction (expect culture $30 \mathrm{~d}$ ) all had a significant effect on number of shoots per explant $(P<0.05$ or $P<0.01)$ (Table 1). There was a significant positive linear correlation between BA concentration and shoots number per explant $(P<0.01)$, whereas media composition had no significant linear correlation $(P>0.05)$ by regression analysis. BA concentration affected shoot formation more than the composition of basal medium did $\left(r_{\mathrm{BA}}>r_{\text {Media }}\right)$.
Media (MSI or 1/2 MSI) supplemented with BA $(2.22$ to $13.32 \mu \mathrm{M})$ alone or in combination with $0.54 \mu \mathrm{M}$ NAA (data not presented) produced healthy shoots without calli in the basal stem area (Fig. 1A-B). However, calli occurred at shoot bases on medium containing NAA greater than 2.68 $\mu \mathrm{M}$ (Fig. 1C) (data not presented). Optimum shoot formation after $50 \mathrm{~d}$ (18.5 shoots/ explant in MSI; 13.4 shoots/explant in $1 / 2$ MSI) occurred on media containing 13.32 $\mu \mathrm{M} B A$ and was significantly higher than on media with other BA concentrations $(P<$ 0.001) (Table 1).

Regression analysis showed media composition and BA concentration had a significant positive linear correlation on $\mathrm{FW}$ gain $(P<0.01)$, whereas no linear correlation was found on the longest leaf length $(P>0.05)$ (Table 1). Media $\times$ BA interaction on leaf length and FW gain, BA concentration on leaf length, and media composition on FW gain all has a significant effect in shoots of $A$. americana $(P<0.01$ or $P<0.05)$ (Table 1$)$. Half-strength MSI supplemented with 8.8 or $13.32 \mu \mathrm{M}$ BA yielded the greatest FW gain $(1.7 \mathrm{~g})$ in each shoot (Table 1). Additionally, leaf length was significantly greater in shoots produced on MSI medium with $2.22 \mu \mathrm{M}$ BA or on $1 / 2 \mathrm{MSI}$ with $13.32 \mu \mathrm{M}$ BA than on media with other PGR treatments $(P<0.001)$ (Table 1).

Callus, shoot induction, and proliferation from leaf segments. Callus, shoot induction, and proliferation were achieved from leaf segments by culturing them on MSI media supplemented with combinations of BA and NAA (Fig. 2A). No shoots were obtained on MSI basal medium without PGRs (control). Different combinations of NAA and BA induced shoot formation (Table 2). Explants placed on media with BA (2.22 to $13.32 \mu \mathrm{M})$ alone or BA $(0.54 \mu \mathrm{M})$ and NAA (2.22 to $4.44 \mu \mathrm{M})$ did not grow or survived initially and then became necrotic. No callus or shoots formed on these explants (Table 2; Fig. 2B).

Calli initiated from the cut edges of $14.6 \%$ to $64.6 \%$ of explants by $30 \mathrm{~d}$ of culture on media containing NAA $(0.54$ to $2.68 \mu \mathrm{M})$ and BA $(8.88$ to $13.32 \mu \mathrm{M})$. One or two adventitious shoots regenerated directly from leaf segments cultured on media with $0.54 \mu \mathrm{M}$ NAA and $8.88 \mu \mathrm{M}$ BA and $0.54 \mu \mathrm{M}$ NAA and $13.32 \mu \mathrm{M}$ BA after $45 \mathrm{~d}$, and these adventitious shoots proliferated an average of 12.5 shoots on medium containing 0.54 $\mu \mathrm{M}$ NAA and $8.88 \mu \mathrm{M}$ BA after $90 \mathrm{~d}$ (Fig. $2 \mathrm{C}-\mathrm{D})$. Green calli formed from leaf segments on medium supplemented with $2.68 \mu \mathrm{M}$ NAA and 8.88 or $13.32 \mu \mathrm{M}$ BA and became white after $60 \mathrm{~d}$. Meanwhile, the explanted leaf segment swelled and by $60 \mathrm{~d}$ of culture became compact, smooth, and two to five times the initial size (Fig. 2E). After this time, the leaf segment turned to a lustrous green and developed many deep green spherical masses by $90 \mathrm{~d}$ (Fig. 2F). After an additional 1 to 2 weeks, these masses developed into shoot clusters (Fig. 2G-H) and produced a mean of 23.4 adventitious shoots (AdS) per explant. Secondary shoots from adventitious shoots were observed after $140 \mathrm{~d}$ of 
Table 1. Effects of 6-benzylaminopurine (BA) concentration on Agave americana proliferation from basal stems. ${ }^{\mathrm{z}}$

\begin{tabular}{|c|c|c|c|c|c|}
\hline \multirow[b]{2}{*}{ Media } & \multirow[b]{2}{*}{$\mathrm{BA}(\mu \mathrm{M})$} & \multicolumn{2}{|c|}{ Shoots per explant } & \multirow{2}{*}{$\begin{array}{l}\text { Longest leaf length }(\mathrm{cm}) \\
\text { After } 30 \mathrm{~d}\end{array}$} & \multirow{2}{*}{$\begin{array}{l}\mathrm{FW}^{\mathrm{y}} \text { gain (g/explant) } \\
\text { After } 30 \mathrm{~d}\end{array}$} \\
\hline & & After $30 \mathrm{~d}$ & After $50 \mathrm{~d}$ & & \\
\hline \multirow{2}{*}{$\overline{\mathrm{MSI}}$} & 4.44 & $6.0 \pm 0.4 \mathrm{~b}$ & $10.8 \pm 1.5 \mathrm{bc}$ & $4.4 \pm 0.3 \mathrm{~b}$ & $1.2 \pm 0.2 \mathrm{abc}$ \\
\hline & 8.88 & $6.8 \pm 0.6 \mathrm{~b}$ & $14.0 \pm 3.1 \mathrm{ab}$ & $5.2 \pm 0.3 \mathrm{ab}$ & $1.0 \pm 0.1 \mathrm{abc}$ \\
\hline \multirow[t]{3}{*}{$1 / 2 \mathrm{MSI}$} & 4.44 & $5.3 \pm 0.5 \mathrm{~b}$ & $6.8 \pm 0.6 \mathrm{~d}$ & $4.0 \pm 0.3 \mathrm{~b}$ & $0.9 \pm 0.3 \mathrm{bc}$ \\
\hline & 8.88 & $5.2 \pm 0.5 \mathrm{~b}$ & $10.0 \pm 0.9 b c$ & $4.9 \pm 0.2 b$ & $1.7 \pm 0.5 \mathrm{a}$ \\
\hline & 13.32 & $6.3 \pm 0.3 \mathrm{~b}$ & $13.4 \pm 0.5 \mathrm{ab}$ & $6.6 \pm 0.5 \mathrm{a}$ & $1.5 \pm 0.7 \mathrm{ab}$ \\
\hline \multicolumn{6}{|c|}{ Analysis of variance ${ }^{x}$} \\
\hline \multirow{3}{*}{$P$ value } & Media & $0.0003 * *$ & $0.0476^{*}$ & $0.2848 \mathrm{Ns}$ & $0.0007 * *$ \\
\hline & BA & $0.0000^{* *}$ & $0.0000 * *$ & $0.0000 * *$ & $0.0943 \mathrm{NS}$ \\
\hline & Media $\times$ BA & $0.0744 \mathrm{NS}$ & $0.0087^{*}$ & $0.0261 *$ & $0.0002 * *$ \\
\hline \multicolumn{6}{|c|}{ Regression analysis $^{x}$} \\
\hline \multirow[t]{2}{*}{ BA-linear } & $p$ & $0.0000 * *$ & $0.0000 * *$ & $0.1147 \mathrm{NS}$ & $0.0159 *$ \\
\hline & $r^{\mathrm{w}}$ & 0.665 & 0.697 & 0.2186 & 0.3804 \\
\hline
\end{tabular}

${ }^{\mathrm{z}}$ Means within a single column followed by different letters within the same column represent significant difference $(P \leq 0.001)$ by the Duncan's multiple range test. Correlation of media, BA, and $\mathrm{m} \times \mathrm{BA}$ interaction to shoots/explant, longest leaf length, and $\mathrm{FW}$ gain was performed by bivariate analysis and linear regression in SPSS 17.0 (SPSS Inc., Chicago, IL).

${ }^{\mathrm{y}} \mathrm{FW}=$ fresh weight.

${ }^{\mathrm{NS}}, *, * *$ Nonsignificant or significant at $P \leq 0.05$ or $\leq 0.01$, respectively.

${ }^{\mathrm{w}} r=$ correlation coefficient of regression analysis.

MSI $=$ modified Murashige and Skoog medium.
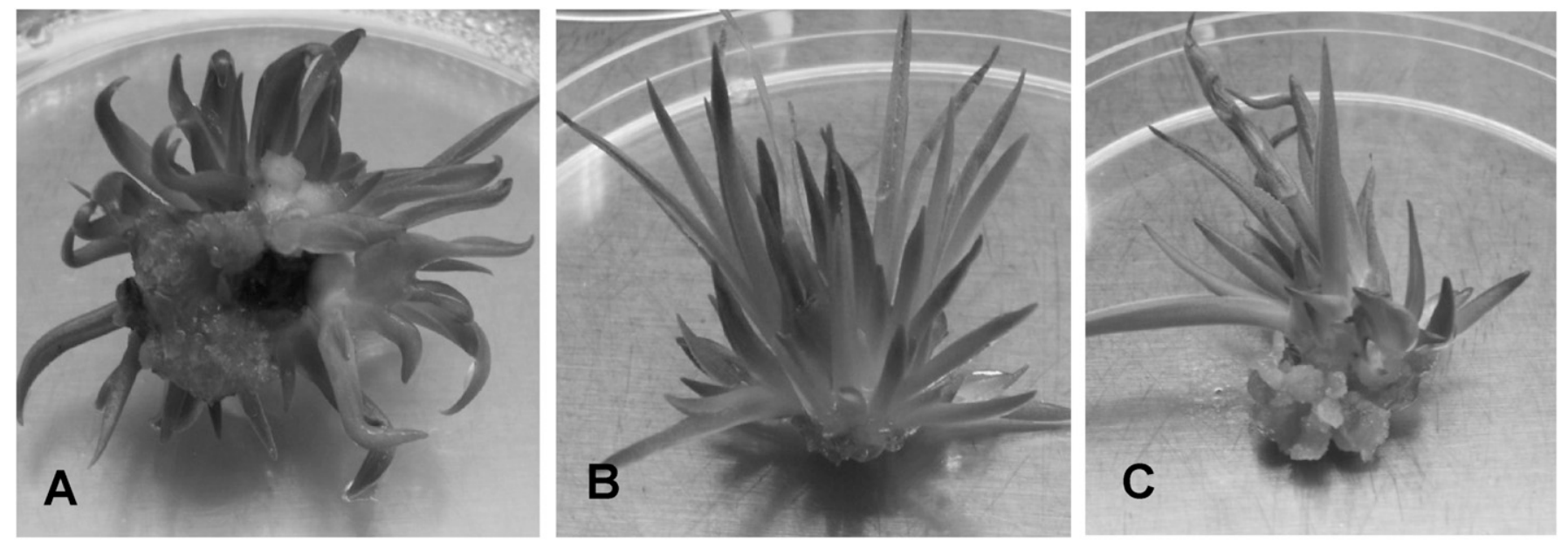

Fig. 1. Shoot formation and development from basal stem of A. americana L. (A-B) Shoot formation from basal stems in medium with BA alone. (C) Callus formed from shoot base in medium with BA and NAA. BA = 6-benzylaminopurine; IBA = indole-3-butyric acid; NAA = $\alpha$-naphthaleneacetic acid.

culture and roots on shoot clusters were occasionally found (Fig. 2I-K).

A higher frequency of explants $(95.6 \%)$ formed calli on media with NAA (2.68 to $5.36 \mu \mathrm{M})$ and BA (2.22 to $13.32 \mu \mathrm{M})$, especially on media with $5.36 \mu \mathrm{M}$ NAA and 4.44 to $13.32 \mu \mathrm{M} \mathrm{BA}$, after $30 \mathrm{~d}$, and were significantly higher than those on explants cultured on other media $(P<0.01)$ (Table 2). Calli formed on media with $5.36 \mu \mathrm{M}$ NAA and 8.88 to $13.32 \mu \mathrm{M}$ BA grew vigorously and were crumbly and loose after $60 \mathrm{~d}$. Hairy roots grew from green callus regions, and afterward, these calli frequently browned and became necrotic. In contrast, green calli formed on media containing 2.68 or $5.36 \mu \mathrm{M}$ NAA combined with $4.44 \mu \mathrm{M}$ BA that became yellowish tissue by $60 \mathrm{~d}$ and subsequently produced many small deep green cell masses dispersed in loose, yellowish calli after
$90 \mathrm{~d}$. These green masses differentiated into visible adventitious shoots by $120 \mathrm{~d}$ (Table 2 ). The highest frequency and number of adventitious shoots per explant were observed on media with $2.68 \mu \mathrm{M}$ NAA and $4.44 \mu \mathrm{M}$ BA $(52.3 \%)(P<0.01)$.

Analysis of variance indicated BA, NAA, and BA $\times$ NAA interaction had significant effects on explant survival, callus response, AdS, and number of AdS per explant $(P<$ $0.01)$. Regression analysis showed that there was a positive linear correlation between NAA concentration and callus response, AdS formation and number of AdS per explant $(P<0.01$ or $P<0.05)$, or between BA concentration and explant survival $(P<0.01$ or $P<0.05$ ) (Table 2).

Explant regions along the leaf for shoots regeneration. Different leaf segments (basal, middle, or apical) from 6-week-old seedlings had significantly different capacities $(P<$ 0.001 ) for forming calli and adventitious shoots. Basal segments generated the highest percentage and mean number of shoots per explant (Table 3 ). These capacities decreased along with the distance of the explant from the leaf base (Table 3).

Basal medium for shoot regeneration. Four basal media, all augmented with 2.68 $\mu \mathrm{M}$ NAA and $13.32 \mu \mathrm{M}$ BA, significantly affected the frequency of adventitious shoot formation from leaf segments and number of adventitious shoots per explant (Table 4). No adventitious shoots formed on WPM medium, whereas $68.8 \%$ of explants grown on MSI medium produced adventitious shoots with 23.4 shoots per explant. This yield was significantly more than those cultured on MS medium (43.8\% explants produced an average of 15.8 shoots per explant). Explants grown on 

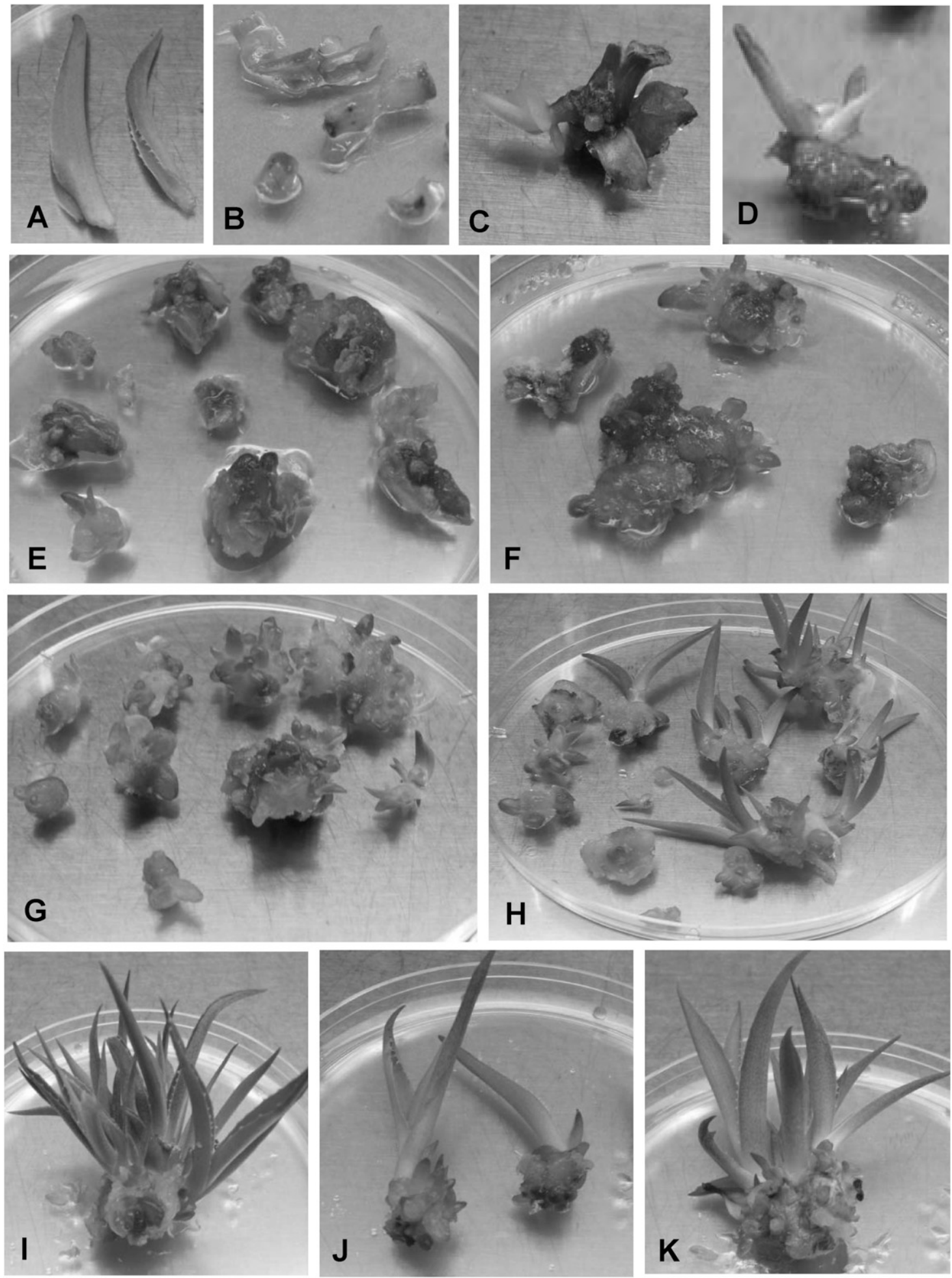

Fig. 2. Adventitious shoots regeneration from leaf explants of $A$. americana. (A) Leaf explants, (B) leaf explant became brown and necrotic in medium without NAA, (C-D) direct shoot regeneration from leaf explants with NAA + BA at $0.54+8.88$ and $0.54+13.32(\mu \mathrm{M}+\mu \mathrm{M})$ after $45 \mathrm{~d}$. (E-H) Adventitious shoots developed in medium with NAA + BA at $2.68+13.32(\mu \mathrm{M}+\mu \mathrm{M})$, leaf segments welled after 80-d culture (E), visible shoots after 90-d culture $(\mathbf{F})$, shoot clusters from one leaf segment $(\mathbf{G}-\mathbf{H})$ for 120-d culture. (I-K) one cluster shoot $(\mathbf{I})$, secondary shoots $(\mathbf{J})$, root formation on some shoots $(\mathbf{K})$ for $140-$ d culture. $\mathrm{NAA}=\alpha$-naphthaleneacetic acid; BA $=6$-benzylaminopurine.

MS medium shoots yielded significantly higher number of shoots than those cultured on DKW medium $(14.3 \%$ explants produced average of eight shoots per explant $)(P<0.01)$.

Histological observation. Histological examination of cultured explants confirmed that direct shoot formation was the method of

HortSCIENCE Vol. 49(3) March 2014 regeneration. Shoots were attached directly to explants tissue by a well-developed vascular cylinder and without an intervening callus (Fig. 3A). Typically the structure of monocot shoot apical meristems and associated primordial leavers was observed in all sections of regenerated shoots (Fig. 3B).
Rooting and plant formation. Shoots (3 to $4 \mathrm{~cm}$ in length) were excised from shoot clusters and transferred to rooting medium. On 1/2 MSI root medium with different concentrations of NAA and IBA, shoots initiated adventitious roots after $10 \mathrm{~d}$ of culture. Rooting percentages and mean numbers of 
Table 2. Effects of $\alpha$-naphthaleneacetic acid (NAA) and 6-benzylaminopurine (BA) on callus and adventitious shoot formation in $A$. americana leaf segments on MSI medium. ${ }^{z}$

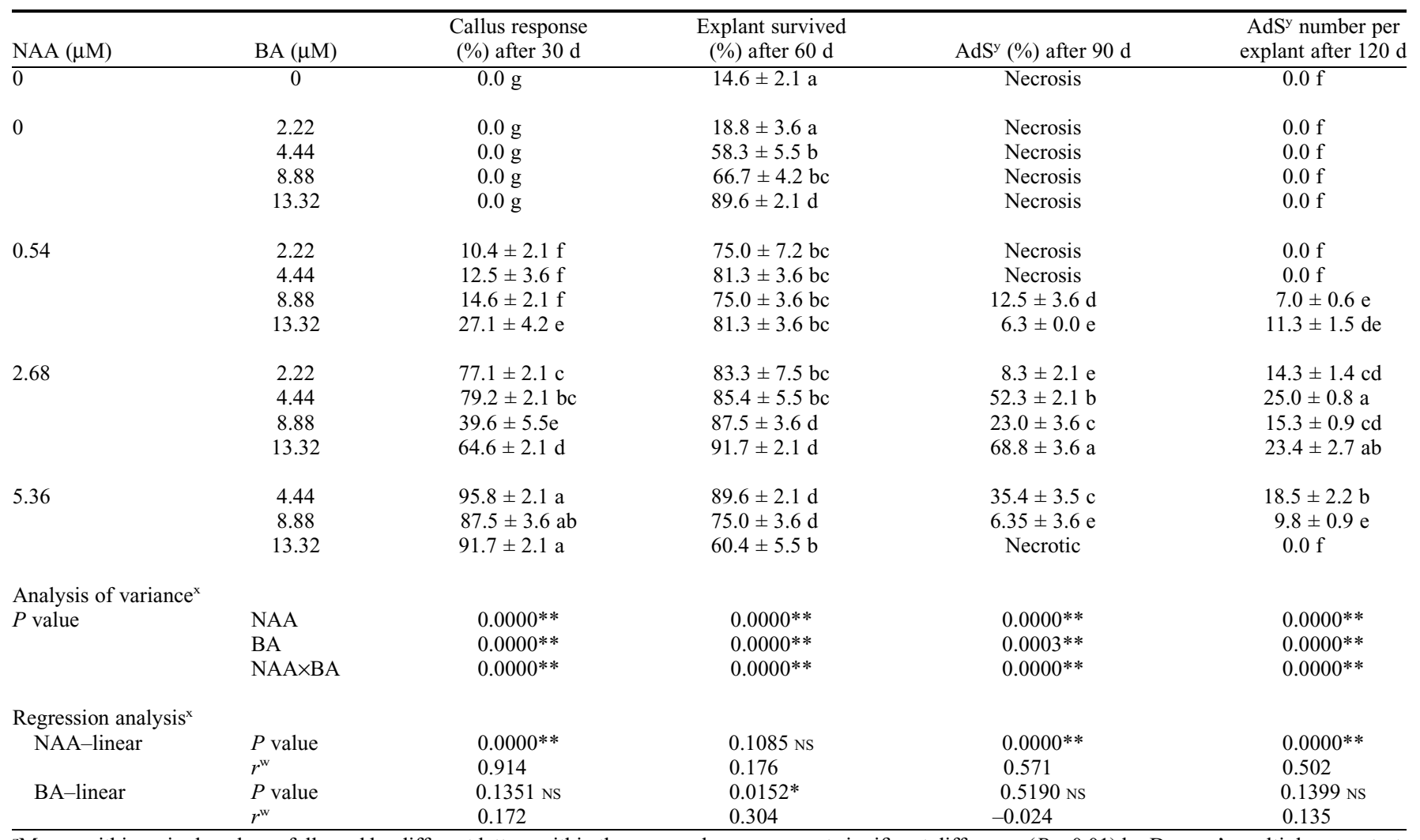

${ }^{\mathrm{z}}$ Means within a single column followed by different letters within the same column represent significant difference $(P<0.01)$ by Duncan's multiple range test. Correlation of NAA, BA, and media NAA $\times$ BA to callus response, explant survival, AdS formation, and no. of AdS per explant were performed by bivariate analysis and linear regression in SPSS 17.0 (SPSS Inc., Chicago, IL).

${ }^{y}$ Adventitious shoots.

${ }^{\mathrm{N}} \mathrm{N}, *, * *$ Nonsignificant or significant at $P \leq 0.05$ or $\leq 0.01$, respectively.

$\mathrm{w}_{r}=$ correlation coefficient of regression analysis.

MSI $=$ modified Murashige and Skoog.

Table 3. Effects of leaf region on shoot regeneration of A. americana cultured on MSI medium. ${ }^{2}$

\begin{tabular}{llccr}
\hline $\mathrm{NAA}+\mathrm{BA}^{\mathrm{y}}(\mu \mathrm{M})$ & Leaf region & $\begin{array}{c}\text { Callus } \\
\text { response }(\%)\end{array}$ & $\begin{array}{c}\text { AdS }^{\mathrm{x}}(\%) \\
\text { after } 90 \mathrm{~d}\end{array}$ & $\begin{array}{r}\text { AdS }^{\mathrm{x}} \text { number per } \\
\text { explant after } 120 \mathrm{~d}\end{array}$ \\
\hline $2.68+13.32$ & Base & $52.0 \pm 2.9 \mathrm{a}$ & $84.6 \mathrm{a}$ & $41.3 \pm 6.5 \mathrm{a}$ \\
& Middle & $38.0 \pm 2.2 \mathrm{~b}$ & $70.6 \mathrm{~b}$ & $24.0 \pm 1.7 \mathrm{~b}$ \\
& Apex & $25.5 \pm 0.9 \mathrm{c}$ & $50.0 \mathrm{c}$ & $5.0 \pm 1.1 \mathrm{c}$ \\
& & & & \\
& Base & $100.0 \pm 0.0 \mathrm{a}$ & $72.2 \mathrm{a}$ & $37.5 \pm 2.1 \mathrm{a}$ \\
& Middle & $84.0 \pm 1.7 \mathrm{~b}$ & $50.0 \mathrm{~b}$ & $22.8 \pm 1.6 \mathrm{~b}$ \\
& Apex & $56.3 \pm 1.8 \mathrm{c}$ & $34.6 \mathrm{c}$ & $14.8 \pm 1.3 \mathrm{c}$ \\
\hline
\end{tabular}

${ }^{\mathrm{z}}$ Means within a single column followed by different letters within the three regions represent significant difference $(P<0.01)$ by Duncan's multiple range test.

${ }^{y} \mathrm{NAA}=\alpha$-naphthaleneacetic acid, an auxin; BA $=6$-benzylaminopurine, a cytokinin.

${ }^{\mathrm{x}}$ Adventitious shoots.

MSI $=$ modified Murashige and Skoog.

Table 4. Effect of basal culture medium with $2.68 \mu \mathrm{M} \alpha$-naphthaleneacetic acid (NAA) and $13.32 \mu \mathrm{M} 6$ benzylaminopurine (BA) on A. americana shoot formation. ${ }^{\mathrm{z}}$

\begin{tabular}{|c|c|c|c|}
\hline Basal medium ${ }^{y}$ & $\begin{array}{c}\text { Callus } \\
\text { response }(\%)\end{array}$ & $\begin{array}{l}\text { AdS }^{\mathrm{x}}(\%) \\
\text { after } 90 \mathrm{~d}\end{array}$ & $\begin{array}{l}\text { AdS }^{\mathrm{x}} \text { number per } \\
\text { explant after } 120 \mathrm{~d}\end{array}$ \\
\hline$\overline{\mathrm{MS}}$ & $50.0 \pm 4.4 \mathrm{~b}$ & $43.8 \pm 3.6 \mathrm{~b}$ & $15.8 \pm 0.8 b$ \\
\hline MSI & $64.6 \pm 2.1 \mathrm{a}$ & $68.8 \pm 3.6 \mathrm{a}$ & $23.4 \pm 2.7 \mathrm{a}$ \\
\hline DKW & $31.7 \pm 1.7 \mathrm{~b}$ & $14.3 \pm 2.2 \mathrm{c}$ & $8.0 \pm 0.8 \mathrm{c}$ \\
\hline WPM & $18.3 \pm 2.9 \mathrm{c}$ & $0.0 \mathrm{~d}$ & $0.0 \mathrm{~d}$ \\
\hline
\end{tabular}

${ }^{\mathrm{z}}$ Means within a single column followed by different letters within the same column represent significant difference $(P \leq 0.01)$ by Duncan's multiple range test.

${ }^{\mathrm{y}} \mathrm{MSI}=$ modified Murashige and Skoog medium; MS = Murashige and Skoog medium (Murashige and Skoog, 1962); DKW = Driver and Kuniyuki Walnut (Driver and Kuniyuki, 1984); WPM = Woody plant medium (Lloyd and McCown, 1981).

${ }^{x}$ Adventitious shoots. roots per shoot were significantly affected by the type and concentration of auxins (Table 5).

Analysis of variance showed significant effects of IBA, NAA, and IBA $\times$ NAA interaction on percentage of root formation and roots number (after culture $20 \mathrm{~d})(P<$ 0.01 or $P<0.05)$. There was a positive linear correlation between IBA concentration and shoots forming percent and roots number per shoot $(P<0.01$ or $P<0.05)$. There was a negative linear correlation between NAA and root formation (\%) after culture $20 \mathrm{~d}(r=$ $-0.314, P<0.05$ ) (Table 5) by regression analysis. It showed IBA was the main effect on shoot rooting in A. americana (positive linear correlation).

Maximum frequency of rooting (90\%) and number of roots (3.4) were both obtained on medium with $4.92 \mu$ M IBA after $20 \mathrm{~d}(P<$ $0.05)$ (Fig. 4A). The highest percentage of rooting (92\%) occurred on medium with 1.48 $\mu \mathrm{M}$ IBA and $1.61 \mu \mathrm{M}$ NAA and the highest number of roots (5.2) happened on a medium with $4.92 \mu \mathrm{M}$ IBA plus $5.34 \mu \mathrm{M}$ NAA (Table 5; Fig. 4B). However, in media supplemented with NAA alone, the rooting frequency and mean number of roots decreased as NAA concentration increased from 0.54 to $5.34 \mu \mathrm{M}$ (negative linear correlation) (Table 5; Fig. 4B). The media with NAA alone induced very low 

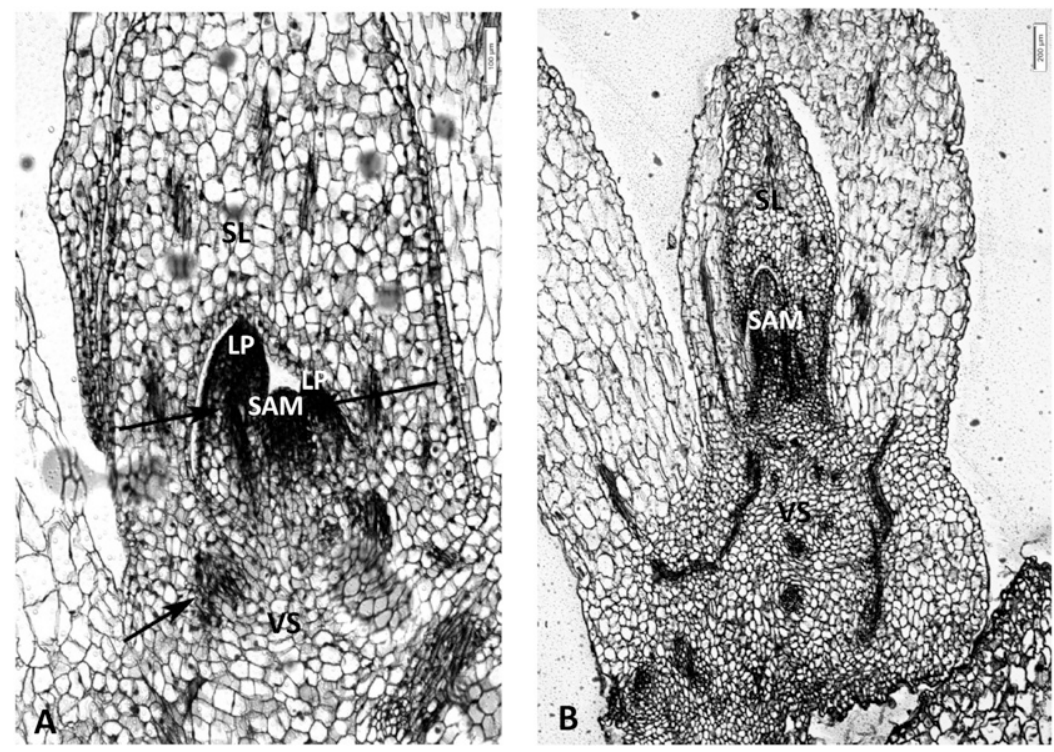

Fig. 3. Histological observations of shoots (organogenesis) developed from leaf segment explant of $A$. americana induced and proliferated in MSI medium supplemented with NAA + BA at $2.68+13.32$ $(\mu \mathrm{M}+\mu \mathrm{M})$. (A) A development shoot derived from the leaf segment explant consists of shoot apical meristem (SAM), leaf primordium (LP), and sheath leaves (SL) and connected with vascular tissue (VS) $(\mathrm{bar}=0.1 \mathrm{~mm}) ;(\mathbf{B})$ a developed and mature shoot $(\mathrm{bar}=0.2 \mathrm{~mm})$. MSI $=$ modified Murashige and Skoog medium; NAA $=\alpha$-naphthaleneacetic acid; BA = 6-benzylaminopurine.

Table 5. Effect of indole-3-butyric acid (IBA) and $\alpha$-naphthaleneacetic acid (NAA) concentrations on roo induction by $A$. americana shoots. $^{2}$

\begin{tabular}{|c|c|c|c|c|c|}
\hline \multirow[b]{2}{*}{ NAA $(\mu \mathrm{M})$} & \multirow[b]{2}{*}{ IBA $(\mu \mathrm{M})$} & \multicolumn{2}{|c|}{ Root $(\%)$} & \multicolumn{2}{|c|}{ Root number per shoot } \\
\hline & & Culture $10 \mathrm{~d}$ & Culture $20 \mathrm{~d}$ & Culture $10 \mathrm{~d}$ & Culture $20 \mathrm{~d}$ \\
\hline$\overline{0}$ & 0 & $0 \mathrm{f}$ & $10 \mathrm{e}$ & $0.0 \pm 0.0 \mathrm{~b}$ & $0.2 \pm 0.1 \mathrm{c}$ \\
\hline 0 & 0.49 & $20 \mathrm{~d}$ & $60 \mathrm{~d}$ & $0.2 \pm 0.1 \mathrm{~b}$ & $1.5 \pm 0.6 \mathrm{bc}$ \\
\hline 0 & 1.48 & $30 \mathrm{c}$ & $80 \mathrm{bc}$ & $0.2 \pm 0.1 \mathrm{~b}$ & $1.8 \pm 0.5 b c$ \\
\hline 0 & 2.46 & $36 \mathrm{c}$ & $81 \mathrm{~b}$ & $0.4 \pm 0.2 \mathrm{~b}$ & $2.6 \pm 0.5 \mathrm{abc}$ \\
\hline 0 & 4.92 & $50 \mathrm{~b}$ & $90 \mathrm{ab}$ & $0.5 \pm 0.2 \mathrm{ab}$ & $3.4 \pm 0.7 \mathrm{ab}$ \\
\hline 0.54 & 0 & $20 \mathrm{~d}$ & $80 \mathrm{bc}$ & $0.2 \pm 0.2 \mathrm{~b}$ & $2.3 \pm 0.7 \mathrm{bc}$ \\
\hline 1.61 & 0 & $10 \mathrm{e}$ & $20 \mathrm{e}$ & $0.1 \pm 0.1 \mathrm{~b}$ & $0.5 \pm 0.3 \mathrm{c}$ \\
\hline 2.68 & 0 & $10 \mathrm{e}$ & $10 \mathrm{e}$ & $0.1 \pm 0.1 \mathrm{~b}$ & $0.1 \pm 0.1 \mathrm{c}$ \\
\hline 5.36 & 0 & $10 \mathrm{e}$ & $10 \mathrm{e}$ & $0.1 \pm 0.1 \mathrm{~b}$ & $0.2 \pm 0.2 \mathrm{c}$ \\
\hline 1.61 & 1.48 & $58 \mathrm{a}$ & $92 \mathrm{a}$ & $0.6 \pm 0.3 \mathrm{ab}$ & $5.0 \pm 1.1 \mathrm{a}$ \\
\hline 2.68 & 2.46 & $50 \mathrm{~b}$ & $80 \mathrm{bc}$ & $0.7 \pm 0.3 \mathrm{ab}$ & $4.0 \pm 1.6 \mathrm{ab}$ \\
\hline 5.36 & 4.92 & $50 \mathrm{~b}$ & $70 \mathrm{c}$ & $0.9 \pm 0.3 \mathrm{a}$ & $5.2 \pm 1.6 \mathrm{a}$ \\
\hline
\end{tabular}

Analysis of variance ${ }^{\mathrm{y}}$

$\begin{array}{llllll}P \text { value } & \text { IBA } & 0.0000^{* *} & 0.0000 * * & 0.0604 \mathrm{NS} & 0.0130 * \\ & \text { NAA } & 0.0000^{* *} & 0.0000^{* *} & 0.6928 \mathrm{NS} & 0.1407 \mathrm{NS} \\ & \text { IBA } \times \text { NAA } & 0.0000^{* *} & 0.0020^{* *} & 0.9683 \mathrm{NS} & 0.0493^{*}\end{array}$

Regression analysis ${ }^{\mathrm{y}}$

\begin{tabular}{llllll} 
NAA-linear & $P$ value & $0.3311 \mathrm{NS}$ & $0.0311^{*}$ & $0.1536 \mathrm{NS}$ & $0.1538 \mathrm{NS}$ \\
& $r^{\mathrm{x}}$ & 0.0754 & -0.314 & 0.0965 & 0.0964 \\
IBA-linear & $P$ value & $0.0000^{* *}$ & $0.0000^{* *}$ & $0.0014^{* *}$ & $0.0450^{*}$ \\
& $r^{\mathrm{x}}$ & 0.7931 & 0.623 & 0.2775 & 0.1596 \\
\hline
\end{tabular}

${ }^{{ }^{2}}$ Means within a single column followed by different letters within the same column represent significant differences $(P \leq 0.05)$ by Duncan's multiple range test. Correlation of IBA, NAA, and IBA $\times$ NAA interaction to root $\%$, no. of roots/explant was performed by bivariate analysis and linear regression in SPSS 17.0 (SPSS Inc., Chicago, IL).

${ }^{\mathrm{N} S}, *, * *$ Nonsignificant or significant at $P \leq 0.05$ or $\leq 0.01$, respectively.

${ }^{\mathrm{x}} r=$ correlation coefficient of regression analysis.

frequencies of rooting ( $10 \%$ to $20 \%$, expect $0.54 \mu \mathrm{M}$ NAA, $80 \%$ ). In addition, callus formed at the shoot bases, indicating that high NAA concentrations inhibited shoot rooting of $A$. americana (Table 5; Fig. 4B). The roots formed from media with $1.48 \mu \mathrm{M}$ IBA plus $1.61 \mu \mathrm{M}$ NAA (92\% rooting) were short and sturdy, and callus grew at their shoot base (Fig. 4B), whereas shoots transferred to media with IBA alone produced long, thin, and delicate roots and no calli. Thus, the medium with $4.92 \mu \mathrm{M}$ IBA alone was considered as the best for inducing roots on $A$. american excised shoots; it produced a high percent of rooting and healthy and the longest roots $(3.5 \mathrm{~cm})$ (Figs. $4 \mathrm{~A}$ and 5$)$.
Plantlet acclimatization. Plantlets from micropropagation transferred to ex vitro conditions and successfully acclimatized to greenhouse conditions, with an $87 \%$ survival rate after $40 \mathrm{~d}$. (Fig. 4C-D). The regenerated plantlets appeared morphologically normal.

\section{Discussion}

Agave americana is a potential bioenergy crop resulting from its large cellulosic biomass with very low lignin (Debnath et al., 2010). Because of its long breeding cycle, we aimed to develop micropropagation and regeneration systems that would be useful in applying in vitro technologies for its improvement such as in vitro mutations and genetic engineering. We achieved rapid micropropagation through culturing basal stems of A. americana, similar to previously reported systems for A. fourcroyde (Robert et al., 1987), A. tequilana (Valenzuela-Sánchez et al., 2006), and $A$. parrasana (Santacruz-Ruvalcaba et al., 1999). Micropropagated shoots can be readily rooted either in vitro or ex vitro, and acclimatized to greenhouse conditions.

The most important factors in successfully micropropagating $A$. american were cytokinin and auxin levels. Cytokinin in the medium was reported to be an essential factor for micropropagating Agave species. Das (1992) and Hazra et al. (2002) both found the highest rates of $A$. sisalana regeneration were obtained using BA as the only PGR. Our results support previous results with Agave species because shoots from basal stems on BA-only medium supported proliferation and produced healthy shoots. We also found that shoot proliferation, leaf length, and FW gain of $A$. americana were influenced by both nutrient salt composition and BA concentration. Low BA and high nutrient salt levels or high BA and low nutrient salt levels were beneficial to leaf elongation.

The exogenous PGR levels, formulation of the basal salts in the medium, and physiological status of the explants can be key factors in shoot induction using leaf as the explant. Leaf segments (A. sisalana) did not develop a callus structure or shoots $(A$. tequilana) supplemented with BA alone or combination with 2,4-dichlorophenoxyacetic acid (2,4-D) in medium (Das, 1992; ValenzuelaSánchez et al., 2006). Shoot regeneration of $A$. sisalana was obtained from compact green callus of immature leaf explants containing BA alone (Hazra et al., 2002). However, leaves of A. tequilana (Portillo et al., 2007) and $A$. salmiana (Flores-Benítez et al., 2007) achieved somatic embryos on MS medium with BA and 2,4-D or BA and NAA.

In our study, the proper concentrations of NAA and BA combination were the most critical factor for inducing shoot formation from leaves. The presence of NAA in the medium was essential for shoot formation (positive linear correlation), but the BA concentration determined the number and formation of shoots. Furthermore, A. americana developed shoots through de novo organogenesis, probably because NAA was used 

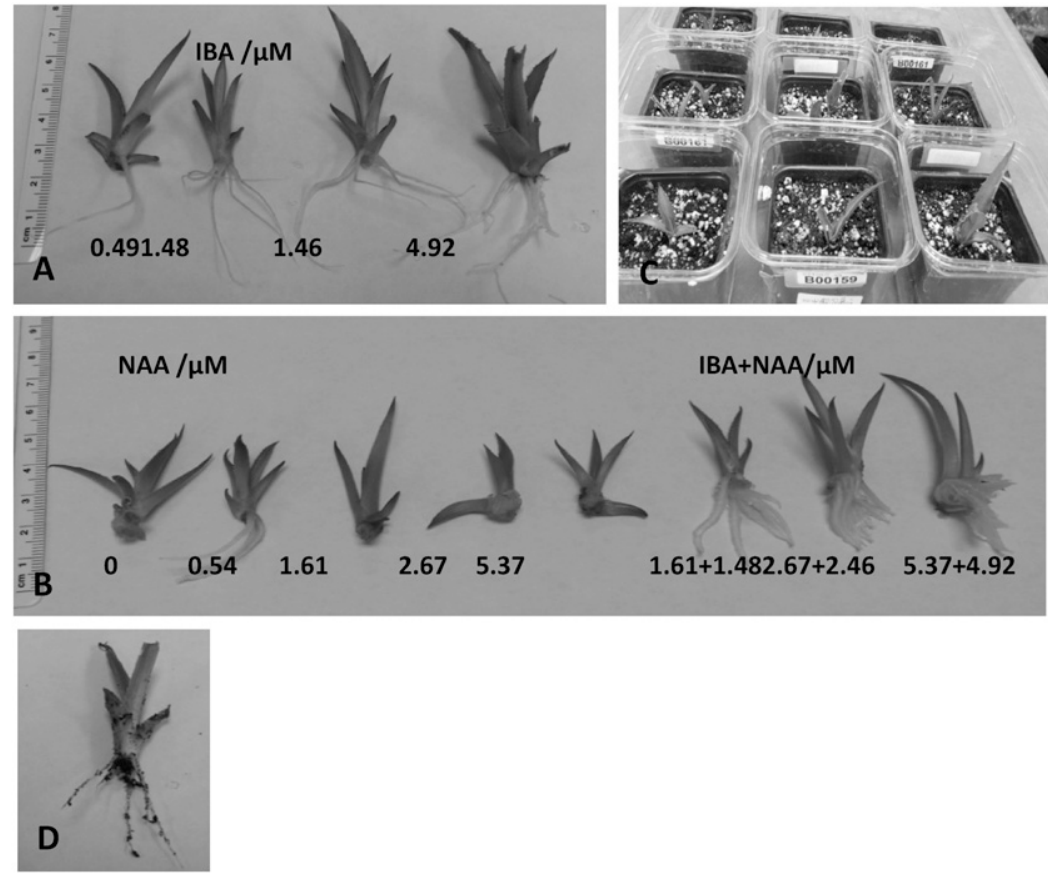

Fig. 4. Effect of IBA and NAA on inducing rooting from shoots and plantlets in ex vitro condition (A) Rooting from shoots at different concentration of IBA; (B) shoots rooting at different concentration of NAA and IBA combination NAA; (C) plantlets in ex vitro condition; (D) shoot rooting in an ex-vitro condition. IBA $=$ indole-3-butyric acid; NAA $=\alpha$-naphthaleneacetic acid.

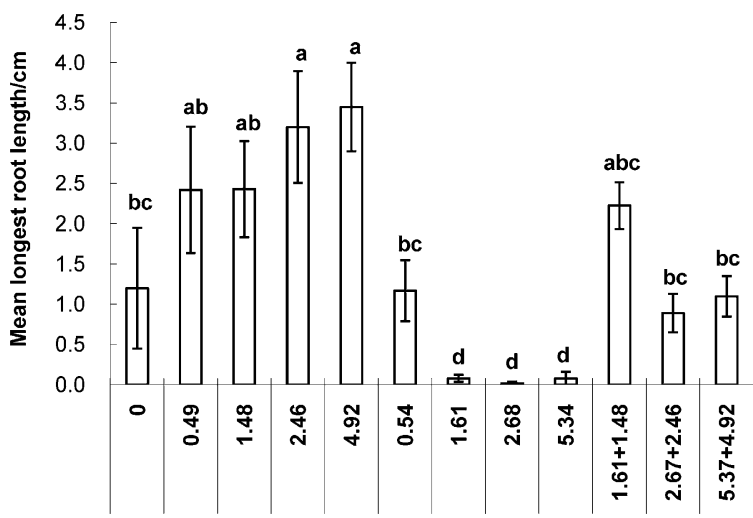

Fig. 5. Effects of different concentrations of indole-3-butyric acid (IBA) and $\alpha$-naphthaleneacetic acid (NAA) on the length of the longest root on Agave americana shoots after $20 \mathrm{~d}$ of culture. Means followed by different letters above the bars indicate significant differences $(P<0.01)$ among treatments according to the Duncan's multiple range test.

instead of 2.4-D. 2,4-D has been shown to be highly potent in inducing somatic embryogenesis, whereas NAA has been used to induce shoot organogenesis when used in combination with cytokinin (Annapurna and Rathore, 2010; Nguyen et al., 2013).

Agave plants have long leaves and leaf length and maturity increases as the plant ages, potentially affecting organogenesis in different leaf regions. Our results showed that the regeneration capacity decreases from the basal end toward to the apical end of the leaf. This result was similar to those by GarciaLuis et al. (2006), Germanà et al. (2008), and Marques et al. (2011), who reported that the best results were obtained using basal segments or regions nearest to the cotyledons.
Goh et al. (1995) and Moreira-Dias et al. (2001) also reported that the epicotyl axis near the base and cotyledons had maximal organogenic potential in Citrus grandis Osbeck and Troyer citrange. Because Agave is a monocotyledenous species, the distal end of the leaves is more mature and, therefore, less responsive to hormones.

Nutrients and vitamins in culture media strongly affect the success of in vitro tissue culture (Rounsaville et al., 2011; Ruzic et al., 2004). The $\mathrm{NO}_{3}^{-}: \mathrm{NH}_{4}{ }^{+}$balance in the medium was a key factor controlling callus growth and organogenesis of A. sisalana (Robert et al., 1987). Valenzuela-Sánchez et al. (2006) used MS medium without glycine, nicotinic acid, or

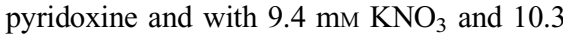

mM $\mathrm{NH}_{4} \mathrm{NO}_{3}$ to induce callus and regenerate plants. In our study, high-salt media (MSI and MS) were beneficial to shoot induction of $A$. americana; lower-salt media such as DKW or WPM were ineffective. Most Agave tissue culture studies have used MS medium (high salt) (Hazra et al., 2002; Martínez-Palacios et al., 2003; Portillo et al., 2012). Thus, a highsalt medium is more favorable for Agave shoot induction. In addition, the vitamin composition is important.

Successful rooting from microcuttings usually depends on the plant species and auxins used. NAA, IBA, and indole-3-acetic acid (IAA) are usually added to media to promote adventitious rooting of cultured shoots. However, shoots of $A$. tequilana (ValenzuelaSánchez et al., 2006), A. arizonica (Powers and Backhaus, 1989), and A. sisalana (Das, 1992) rooted in PGR-free medium. However, shoots of $A$. fourcroydes (Robert et al., 1987, 2006) and A. sisalana (Hazra et al., 2002) required both 2,4-D and IAA for rooting to occur. In our study, the rooting rate of $A$. americana was very low (10\%) in PGR-free medium, but medium with IBA alone or in combination with NAA yielded a high rooting frequency (greater than 90\%) of individual shoots and number of roots, whereas NAA alone at high concentrations inhibited rooting. Similar results were reported for $A$. attenuate (Li et al., 2003), Rosa kordesii (Arnold et al., 1995), and Camptotheca acuminate (Chen et al., 2004), suggesting that plant species require different auxins and concentrations to stimulate adventitious rooting.

In conclusion, we have developed a shoot propagation protocol for $A$. americana using basal stems. The optimum medium for proliferation is MSI contains $13.32 \mu \mathrm{M}$ BA. This protocol can be used to mass production for experimental materials and elite clones from a breeding program in vitro manipulation. We also developed a protocol for plant generation through shoot formation from leaf explants through organogenesis. The optimum protocol uses basal sections of leaf tissues and culture on MSI media containing $2.68 \mu \mathrm{M}$ NAA and $13.32 \mu \mathrm{M}$ BA. The optimum medium for shoots rooting is $1 / 2 \mathrm{MSI}$ containing $4.92 \mu \mathrm{M}$ IBA alone. This is the first complete protocol for the micropropagation and plant regeneration of $A$. americana. The plant regeneration protocol is a prerequisite for many in vitro manipulation technologies such as in vitro mutation, selection, and genetic engineering.

\section{Literature Cited}

Annapurna, D. and T.S. Rathore. 2010. Direct adventitious shoot induction and plant regeneration of Embeliaribes Burm F.. Plant Cell Tiss. Org. Cult. 101:269-277.

Arnold, N.P., M.R. Binns, D.C. Cloutier, N.N Barthakur, and R. Pellerin. 1995. Auxins, salt concentrations, and their interactions during in vitro rooting of winter-hardy and hybrid tea roses. HortScience 30:1436-1440.

Chen, Y., F.L. Cao, S.X. Li, and Y.F. Xie. 2004. Adventitious bud induction and establishment of a regeneration system in shoots of 
Camptothecaacuminata [in Chinese]. Nonwood For. Res. 22:8-11.

Das, T. 1992. Micropropagation of Agave sisalana. Plant Cell Tiss. Org. Cult. 31:253-255.

Debnath, M., M. Pandey, R. Sharma, G.S. Thakur, and P. Lal. 2010. Biotechnological intervention of Agave Sisalana: A unique fiber yielding plant with medicinal property. J. Med. Plants Res 4:177-187.

Driver, J.A. and A.H. Kuniyuki. 1984. In vitro propagation of Paradox walnut rootstock. HortScience 19:507-509.

Duncan, D.B. 1955. Multiple range and multiple F test. Biometrics 11:1-42.

Flores-Benítez, J. S., J. F. Jiménez-Bremont, S. Rosales-Mendoza, G. R. Argüello-Astorga, R. Castillo-Collazó, and G. Alpuche-Solís. 2007. Genetic transformation of Agave salmiana by Agrobacterium tumefaciens and particle bombardment. Plant Cell Tiss. Org. Cult. 91:215224.

Garcia-Luis, A., R. V. Molina, V. Varona, S. Castello, and J. L. Guardiola. 2006. The influence of explant orientation and contact with the medium on the pathway of shoot regeneration in vitro in epicotyl cuttings of Troyer citrange. Plant Cell Tiss. Org. Cult 85:137-144.

Garcia-Moyae, E., A. Romero-Manzanares, and P.S. Nodel. 2011. Highlights for Agave productivity. GCB Bioenergy 3:4-14.

Germanà, M.A., L. Macaluso, G. Patricolo, and B. Chiancone. 2008. Morphogenic response in vitro of epicotyl segments of Citrus macrophylla. Plant Biosyst. 142:661-664.

Goh, C.J., G.E. Sim, C. L. Morales, and C. S. Loh. 1995. Plantlet regeneration through different morphogenic pathways in pommelo tissue culture. Plant Cell Tiss. Org. Cult. 43:301-303.

González, G., S. Aleman, and D. Infante. 2003. Asexual genetic variability in Agave fourcroydes. II: Selection among individuals in a clonally propagated population. Plant Sci. 165: 595-601.

Hazra, S.K., S. Das, and A.K. Das. 2002. Sisal plant regeneration via organogenesis. Plant Cell Tiss. Org. Cult. 70:235-240.

Jaouadi, M., S. Mashli, and F. Sakli. 2011. A study of the physical and mechanical properties of paper made from Agave americana L. fibers. Mater. Manuf. Proces. 26:567-572.

Jensen, W.A. 1962. Botanical histochemistry. Principles and practice. Freeman, San Francisco, CA.
Jin, J. M., X. K. Liu, and C.R. Yang. 2003. Three new hecogenin glycosides from fermented leaves of Agave Americana. J. Asian Nat. Prod. Res. 5:95-103.

Jin J. M., Zhang, Y. J., and C.R. Yang. 2004. Four new steroid constituents from the waste residue of fibre separation from Agave americana leaves. Chem. Pharm. Bull. (Tokyo) 52:654 658.

Lachenmeier, D. W., E. M. Sohnius, R. Attig, and M. G. Lopen. 2006. Quantification of selected volatile constituents and anions in Mexican Agave spirits (tequila, mezcal, sotol bacanora). J. Agr. Food Chem. 54:3911-3915.

Li, Y., J.F. Yang, and C.C. Zhang. 2003. Tissue culture and rapid propagation of Agave attenuate [in Chinese]. Plant Physiol. Commun. 39:474.

Lloyd, G. and B.H. McCown. 1981. Commercially feasible micropropagation of Mountain Laurel, Kalmia latifolia, by shoot tip culture. Proc. Intl. Plant Prop. Soc. 30:421-427.

Marques, N. T., G. B. Nolasco, and J. P. Leitao. 2011. Factors affecting in vitro adventitious shoot formation on internode explants of Citrus aurantium L. cv. Brazilian. Sci. Hort. 129:176182.

Martínez-Palacios, A., M. P. Ortega-Larrocea, M. V. Chavez, and R. Bye. 2003. Somatic embryogenesis and organogenesis of Agave victoriareginae: Considerations for its conservation. Plant Cell Tiss. Org. Cult. 74:135-142.

Moreira-Dias, J. M., R. V. Molina, J. L. Guardiola, and A. Garcia-Luis. 2001. Day length and photon flux density influence the growth regulator effects on morphogenesis in epicotyl segments of Troyer citrange. Sci. Hort. 87:275-290.

Murashige, T. and F. Skoog. 1962. A revised medium for rapid growth and bioassays with tobacco tissue culture. Physiol. Plant. 15:473-494.

Nasri, S. and H. Ben Salemn. 2012. Effect of oral administration of Agave americana or Quillajasaponaria extracts on digestion and growth of Barbarine female lamb. Livest. Sci. 147:59-65.

Nguyen, Q.V., H.J. Sun, K. Boo, H. Lee, J.H. Lee, P.O. Lim, H.Y. Lee, K.Z. Riu, and D.S. Lee. 2013. Effect of plant growth regulator combination and culture period on in vitro regeneration of spinach (Spinacia oleracea L.). Plant Biotechnol. Rep. 7:99-108.

Nikam, T.D., G.M. Bansude, and K. Aneesh. 2003. Somatic embryogenesis in sisal (Agave. sisalana Perr. Ex. Englem). Plant Cell Rpt. 22:188-194.
Portillo, L., A. Olmedilla, and F. SantacruzRuvalcaba. 2012. Cellular and molecular changes associated with somatic embryogenesis induction in Agave tequilana. Protoplasma. 249:1101-1107.

Portillo, L., F. Santacruz-Ruvalcaba, A. GutierrezMora, and B. Rodriguez-Garay. 2007. Somatic embryogenesis in Agave tequilana Weber cultivar azul. In Vitro Cell Dev. Biol. Plant. 43:569-575.

Powers, D.E. and R.A. Backhaus. 1989. In vitro propagation of Agave arizonica Gentry and Weber. Plant Cell Tiss. Org. Cult. 16:57-60.

Robert, M. L., J. L. Herrera, E. Castillo, G. Ojeda, and M.A. Herrera-Alamillo. 2006. An efficient method for the micropropagation of Agave species. Methods Mol. Biol. 318:165-178.

Robert, M.L., J.L. Herrera, F. Contreras, and K.N. Scorer. 1987. In vitro propagation of Agave fourcroydes Lem. (Henequen). Plant Cell Tiss. Org. Cult. 8:37-48.

Rodriguez-Sahagun, A., G. Acevedo-Hernandez, J. M. Rodriguez-Dominguez, B. Rodriguez-Garay, J. Cervantes-Martinez. and O.A. CastellanosHernadez. 2011. Effect of light quality and culture medium on somatic embryogenesis of Agave tequilana Weber var. Azul. Plant Cell Tiss. Org. Cult. 104:271-275.

Rounsaville, T.J., D.H. Touchell, T.G. Ranney, and F.A. Blazich. 2011. Micropropagation of Mahonia 'Soft Caress'. HortScience 46:1010-1014.

Ruzic, D., M. Saric, R. Cerovic, and L. Culafic. 2004. Contents of macroelements and growth of sweet cherry rootstock in vitro. BMC Plant Biol. 7:463-465.

Santacruz-Ruvalcaba, F., H. Gutierrez-Pulido, and B. Rodriguez-Garay. 1999. Efficient in vitro propagation of Agave parrasana Berger. Plant Cell Tiss. Org. Cult. 56:163-167.

Santacruz-Ruvalcaba, F. and L. Portillo. 2009. Thin cell suspension layer as a newmethodology for somatic embryogenesis in Agave tequilana Weber cultivar azul. Ind. Crops Prod. 29:609-614.

Somerville, C., H. Youngs, C. Taylor, S.C. Davis, and S. P. Long. 2010. Feedstocks for lignocellulosic biofuels. Science 329:790-792.

Valenzuela-Sánchez, K.K., R. E. Juarez-Hernandez, A. Cruz-Hernandez, V. Olalde-Portugal, M.E. Valverde, and O. Paredes-Lopez. 2006. Plant regeneration of Agave tequilana by indirect organogenesis. In Vitro Cell. Dev. Biol. Plant 42:336-340. 